\title{
40. NATURAL REMANENT MAGNETIZATION, MAGNETIC PROPERTIES, AND OXIDATION OF TITANOMAGNETITE IN BASALTIC ROCKS FROM DSDP LEG 34
}

\author{
Sherman Grommé and Edward A. Mankinen, U.S. Geological Survey, Menlo Park, California
}

\section{INTRODUCTION}

We have made paleomagnetic measurements and investigated the magnetic mineralogy of 24 samples of basalt and diabase from Sites 319,320 , and 321 on the Nazca plate. Sample distributions, locations, and ages of overlying sediments are as follows: Site 319, Hole 319, lat $13^{\circ} 01.04^{\prime} \mathrm{S}$, long $101^{\circ} 31.46^{\prime} \mathrm{W}, 2$ samples, early Miocene (N8); Site 319, Hole 319A, (same coordinates and age), 12 samples. Site 320 , Hole $320 \mathrm{~B}$, lat $9^{\circ} 00.40^{\prime} \mathrm{S}$, long $83^{\circ} 31.80^{\prime} \mathrm{W}, 2$ samples, late Oligocene (N2); Site 321 , lat $12^{\circ} 01.29^{\prime} \mathrm{S}$, long $81^{\circ} 54.24^{\prime} \mathrm{W}, 8$ samples, late Eocene (P16). The objectives were (1) to investigate the stability of the natural remanent magnetization (NRM), (2) to evaluate an improved method of alternating-field (AF) demagnetization, (3) to determine the directions of the magnetically stable components of NRM and the approximate in-situ intensities of NRM, (4) to identify the ferrimagnetic minerals and determine their degree of oxidation, and (5) to relate this oxidation to the magnetic characteristics of the minerals.

\section{EXPERIMENTAL METHODS}

The samples were short cores $(2.54 \mathrm{~cm}$ dia $\times 1.73 \mathrm{~cm}$ long) cut horizontally from the original core segments. This length/diameter ratio $(0.68)$ is less than the optimal value of 0.91 required to eliminate errors because of deflection of induced magnetization arising from bulk shape anisotropy of susceptibility when measuring NRM with a spinner magnetometer. Furthermore, nearly all workers investigating deep-sea basalts obtained by DSDP have reported instability of NRM due to large components of viscous remanent magnetization (VRM) with very short time constants. This ability of the samples to acquire VRM in the laboratory is greatly enhanced by AF demagnetization. For these reasons, most NRM measurements were made in field-free space, and when progressive AF demagnetization experiments were begun, all samples were stored in field-free space. Prior to AF demagnetization, the NRM of each sample was measured seven times over a period of several weeks to two months. Three of these measurements were made using a $109-\mathrm{Hz}$ spinner magnetometer operating in the earth's field (Doell and Cox, 1965), and four were made using a $5-\mathrm{Hz}$ spinner magnetometer operating in a 4layer $\mu$-metal shield that reduced the ambient field to less than 20 gammas. No systematic differences in measurements of direction or intensity of NRM were observed between these two magnetometers. During AF demagnetization, all measurements were made with the $5-\mathrm{Hz}$ magnetometer.

AF demagnetization was done at $60 \mathrm{~Hz}$ using equipment modified from the design of Doell and Cox (1967a). The modification consists only of adding a fourth axis of rotation to the three-axis tumbler used previously (R.R. Doell, oral communication, 1965). Because spurious components of remanence are readily acquired by submarine basalts (and many other rocks) during AF demagnetization, a modification of the usual procedure was followed. Doell and Cox (1967a) had found that the major part of the spurious remanence was acquired along the direction parallel to the innermost rotation axis of the tumbler, i.e., the axis that is invariant with respect to the rock sample. Wilson and Lomax (1972) made a detailed study of this effect and found that the acquired remanence, termed rotational remanent magnetization (RRM), was reproducibly dependent on the strength of the alternating field and its frequency and on the speed of rotation. Wilson and Lomax (1972) also found that, although the magnitude of RRM is very dependent on the type of rock sample, the polarity of RRM is invariably opposite to the sense of the rotation vector of the sample. Using three- and four-axis tumblers, we have confirmed the results of Wilson and Lomax (1972) to this extent: the magnitude of RRM depends on peak alternating field strength, and the polarity of RRM depends invariably on the direction of tumbler rotation. To compensate for this effect, during progressive demagnetization each specimen was demagnetized and measured twice at each increment of alternating field, and for the second of each pair the sample was reversed $180^{\circ}$ with respect to the innermost tumbler axis. We make the following two assumptions: (1) for each of the paired demagnetizations the RRM is equal in magnitude but opposite in sign to the other, and (2) the NRM is only changed by the first demagnetization, not by the repeat experiment. If these are true, then the true NRM at each step is simply equal to one-half the vector sum of the paired measurements, and we have used this method of calculation in the present work.

Weak-field susceptibilities were measured at $1000 \mathrm{~Hz}$ with a commercial bridge. Saturation magnetizations were obtained from magnetization curves in fields from 0 to 8000 oe and were calculated so as to eliminate the contribution from paramagnetic minerals, i.e., the reported values are for the bulk rock but represent only the contribution due to the ferrimagnetic minerals. Strong-field thermomagnetic curves were obtained with an automatic recording magnetic balance (Doell and Cox, 1967b; Grommé et al., 1969). All initial runs were made in vacuum (less than $10^{-4}$ torr) to slightly more than $600^{\circ} \mathrm{C}$, at heating and cooling rates of $10^{\circ}$ or $15^{\circ} \mathrm{C} / \mathrm{min}$. Additional specimens from all samples having Curie temperatures less than $200^{\circ} \mathrm{C}$ were also run in nitrogen gas to $300^{\circ}$ or $400^{\circ} \mathrm{C}$. Although the vacuum in this apparatus is not particularly high, the actual oxygen 
fugacity is extremely low, about $10^{-23}$ bar at $350^{\circ} \mathrm{C}$, because of the presence of hydrocarbon vapor from the vacuum diffusion pump (Marshall and Cox, 1972). This condition effectively inhibits oxidation of titanomagnetite, but the absence of gas in the apparatus prevents accurate temperature measurement below $200^{\circ} \mathrm{C}$. Hence in order to measure low Curie temperatures accurately, nitrogen had to be used, although oxidation of specimens occurred at temperatures above $300^{\circ} \mathrm{C}$. Curie temperatures were determined by a simple graphical method (Grommé et al., 1969; Readman and O'Reilly, 1972). Magnetic concentrates were obtained by hand crushing and grinding under acetone and using a hand magnet for separation. Cubic cell dimensions of the magnetic concentrates were obtained from the (311), (400), (333), and (440) reflections using $\mathrm{Cu} \mathrm{Ka}$ radiation and a spinel internal standard. Densities were determined by measuring weight and volume.

\section{NATURAL REMANENT MAGNETIZATION}

Intensities, inclinations, and relative declinations of NRM are given in Table 1. These entries are the means of the seven sets of replicate measurements made prior to demagnetization. (Relative declinations are given only for comparison with directions after demagnetization and have no other significance.) Also given in Table 1 are standard deviations of the intensities and rms angular deviations of the directions from the means (Wilson, 1959). Standard deviations of intensities range from $2 \%$ to $22 \%$ and are very well correlated with rms angular deviations, indicating the relative ease with which many of these samples acquired viscous magnetization in their virgin state in the laboratory.

Intensities of NRM range from $0.24 \times 10^{-3} \mathrm{emu} / \mathrm{cc}^{3}$ to $16.3 \times 10^{-3} \mathrm{emu} / \mathrm{cc}^{3}$ (Table 1). These values are roughly one-half to one-tenth of those previously reported for dredged fragments of submarine pillow basalt (Irving et al., 1970b; Marshall and Cox, 1971; Fox and Opdyke, 1973; Prévot and Grommé, 1975). Measured susceptibilities range from $0.01 \times 10^{-3} / \mathrm{cc}$ to $5.1 \times 10^{-3} / \mathrm{cc}$ (Table 1) and average about $2 \times 10^{-3}$, about four to five times greater than values for dredged pillow basalt fragments reported by Marshall and Cox (1971), Fox and Opdyke (1973), and Irving et al. (1970b). We note, however, that the NRM intensities and the susceptibilities listed in Table 1 are very similar to values found by Lowrie et al. (1973) and M. Marshall (written communication, 1974) for DSDP basalts obtained from the Pacific plate. $Q$, the in situ ratio of remanent to induced magnetization, was calculated for each sample using a local geomagnetic field intensity of 0.31 oe and is listed in Table 1. $Q$ ranges from 1 to 25 , and in general, the NRM intensity is only approximately correlated with susceptibility in these samples.

AF demagnetization was performed on all samples, either to a peak field of 800 oe or, more commonly, until the remanent intensity was $10 \%$ of the initial value. Representative AF demagnetization curves are shown in Figure 1. When, as in Figure 1, the logarithm of magnetization is plotted against the demagnetizing field, most data for individual samples fall on quasi-straight lines, the slopes of which might be used to characterize the magnetic hardness of NRM. These samples exhibit a wide variation of magnetic hardness, but most are rather soft, and the curves for Samples 319-13-1, $138 \mathrm{~cm}, 319 \mathrm{~A}-$ $5-1,68 \mathrm{~cm}$, and 321-14-2, $122 \mathrm{~cm}$ in Figure 1 are most typical. The hardness of NRM is more commonly characterized by the median demagnetizing field (MDF), defined as the peak alternating field required to reduce the NRM intensity to one-half its initial value. MDF values for all specimens are listed in Table 1; they range from 35 oe to more than 800 oe, but only two are greater than $300 \mathrm{oe}$. This distribution is similar to that found by Lowrie et al. (1973) for Pacific plate DSDP basalts.

The variation of inclination of NRM during AF demagnetization is shown for all specimens in Figure 2. In this figure, the short vertical bars join the two measured inclinations obtained from each of the paired demagnetizations, and the true inclination, calculated as described above, is indicated by a circle. Where only a circle is shown, the two measured inclinations did not differ significantly. The optimum demagnetizing field, determined by considering both inclination and declination, is shown in Figure 2 by a short arrow for each specimen. It is clear from this figure that use of the double demagnetization procedure allows valid measurements to be obtained at much higher alternating fields than otherwise possible. Moreover, for the magnetically softer rocks, the optimum demagnetizing field is generally twice that at which the RRM would produce a significant error in the measured inclination.

All samples carried at least one component of secondary magnetization, many of which were very large, that were completely removed at the optimum demagnetizing fields listed in Table 1 and shown in Figure 2. In addition, the two specimens from Hole 319 and the uppermost four specimens from Hole 319A carried another very soft secondary magnetization, nearly or completely removed in an alternating field of 25 oe. Presence of this very soft component is unrelated to MDF values or to the dispersion of the repeated NRM measurements. The vertical component of the main secondary magnetization was directed downward for Hole 319 and Site 321, and upward for Holes 319A and 320B. The largest secondary magnetization was found in Sample 319A-2-1, $87 \mathrm{~cm}$, but the inclination after demagnetization is anomalous (Table 1). This anomaly will be discussed more fully in a later section.

Inclinations and relative declinations computed after optimum demagnetization are given in Table 1 . In the three pairs of specimens that were cut from single or interlocking core segments (Hole 319, Core 13; Hole $319 \mathrm{~A}$, Cores 4 and 5), the relative delinations differ by no more than $3^{\circ}$. In the two specimens from Core 319A5 , however, the inclinations differ by $10^{\circ}$ (see Figure 2), which may result from error in specimen orientation.

The stable NRM inclinations might best be compared with the inclinations that would be predicted at the sites using the model of a geocentric axial dipole field of either polarity. The results are: Site 319, predicted $I=$ $\pm 24.8^{\circ}$, mean measured $I=58.4^{\circ}$ (excluding Sample $319 \mathrm{~A}-2-1,87 \mathrm{~cm}$ ). Site 320 , predicted $I= \pm 17.6^{\circ}$, mean measured $I=-19.6^{\circ}$ (for two specimens only). Site 321, predicted $I= \pm 23.0^{\circ}$, mean measured $I=-16.2^{\circ}$. These 
TABLE 1

Intensities, Inclinations, and Relative Declinations of NRM and Other Magnetic Properties

\begin{tabular}{|c|c|c|c|c|c|c|c|c|c|c|c|c|c|c|c|c|c|c|c|c|}
\hline $\begin{array}{c}\text { Sample } \\
\text { (Interval in } \mathrm{cm} \text { ) }\end{array}$ & $\rho$ & $x$ & $Q$ & $J_{N}$ & $\mathrm{SD} J_{N}$ & $I_{N}$ & $D_{N}$ & $\delta_{N}$ & MDF & $H$ & $J_{H}$ & ${ }^{I} H$ & $D_{H}$ & $J_{s}$ & $T_{c}$ & Type & $a$ & $z\left(\mathbf{T}_{\mathrm{C}}\right)$ & $z$ (a) & $z$ (Fig. 4) \\
\hline \multicolumn{21}{|l|}{ Hole 319} \\
\hline $\begin{array}{l}13-1,138-141 \\
13-1,144-147\end{array}$ & $\begin{array}{l}2.92 \\
2.90\end{array}$ & $\begin{array}{l}0.47 \\
0.66\end{array}$ & $\begin{array}{l}4.3 \\
1.9\end{array}$ & $\begin{array}{l}0.63 \\
0.40\end{array}$ & $\begin{array}{l}0.11 \\
0.07\end{array}$ & $\begin{array}{l}39.8 \\
76.2\end{array}$ & $\begin{array}{r}7.5 \\
103.1\end{array}$ & $\begin{array}{l}12.1 \\
25.6\end{array}$ & $\begin{array}{r}75 \\
110\end{array}$ & $\begin{array}{l}200 \\
200\end{array}$ & $\begin{array}{l}1.03 \\
1.00\end{array}$ & $\begin{array}{l}51.0 \\
48.8\end{array}$ & $\begin{array}{l}23.4 \\
22.8\end{array}$ & $\begin{array}{l}0.37 \\
0.59\end{array}$ & $\begin{array}{l}278 \\
242\end{array}$ & $\begin{array}{l}\mathrm{D} \\
\mathrm{D}\end{array}$ & 8.393 & $\begin{array}{l}0.70 \\
0.60\end{array}$ & 0.80 & 0.79 \\
\hline \multicolumn{21}{|l|}{ Hole 319A } \\
\hline $\begin{array}{l}1-1,23-26 \\
1-1,42-45 \\
2-1,87-90 \\
2-3,75-78 \\
3-3,110-113 \\
3-5,78-81 \\
4-1,119-122 \\
4-1,123-126 \\
5-1,68-71 \\
5-1,84-87 \\
7-1,68-71 \\
7-1,96-99\end{array}$ & $\begin{array}{l}2.88 \\
2.92 \\
2.86 \\
2.84 \\
2.88 \\
2.88 \\
2.91 \\
2.92 \\
2.91 \\
2.93 \\
2.86 \\
2.89\end{array}$ & $\begin{array}{l}0.22 \\
0.56 \\
0.51 \\
0.13 \\
3.31 \\
3.03 \\
2.47 \\
2.83 \\
2.98 \\
2.72 \\
0.34 \\
0.22\end{array}$ & $\begin{array}{r}3.7 \\
2.8 \\
3.8 \\
6.1 \\
1.1 \\
1.9 \\
3.4 \\
2.8 \\
2.5 \\
3.3 \\
24.7 \\
23.2\end{array}$ & $\begin{array}{l}0.25 \\
0.48 \\
0.60 \\
0.24 \\
1.08 \\
1.77 \\
2.60 \\
2.49 \\
2.30 \\
2.75 \\
2.61 \\
1.60\end{array}$ & $\begin{array}{l}0.01 \\
0.08 \\
0.03 \\
0.01 \\
0.19 \\
0.39 \\
0.34 \\
0.27 \\
0.21 \\
0.34 \\
0.07 \\
0.06\end{array}$ & $\begin{array}{r}10.2 \\
-24.5 \\
35.6 \\
52.0 \\
43.4 \\
39.2 \\
-5.5 \\
-21.8 \\
27.7 \\
19.2 \\
41.2 \\
45.9\end{array}$ & $\begin{array}{r}144.4 \\
342.0 \\
53.9 \\
204.8 \\
268.3 \\
213.4 \\
350.5 \\
353.5 \\
127.5 \\
168.4 \\
66.5 \\
18.8\end{array}$ & $\begin{array}{r}3.1 \\
12.7 \\
5.8 \\
1.9 \\
21.1 \\
16.0 \\
5.9 \\
6.6 \\
6.6 \\
6.6 \\
1.6 \\
1.4\end{array}$ & $\begin{array}{r}175 \\
180 \\
80 \\
175 \\
70 \\
60 \\
70 \\
75 \\
80 \\
70 \\
200 \\
280\end{array}$ & $\begin{array}{l}300 \\
300 \\
250 \\
200 \\
200 \\
250 \\
200 \\
150 \\
150 \\
200 \\
200 \\
250 .\end{array}$ & $\begin{array}{r}0.31 \\
1.47 \\
0.43 \\
1.31 \\
1.04 \\
0.54 \\
3.32 \\
4.34 \\
9.28 \\
4.04 \\
12.90 \\
9.02\end{array}$ & $\begin{array}{r}48.6 \\
46.6 \\
-70.4 \\
56.7 \\
68.4 \\
84.7 \\
63.9 \\
63.1 \\
55.6 \\
65.9 \\
49.2 \\
52.9\end{array}$ & $\begin{array}{r}131.2 \\
190.1 \\
230.6 \\
214.0 \\
20.7 \\
344.5 \\
354.1 \\
357.3 \\
143.8 \\
145.4 \\
64.4 \\
9.0\end{array}$ & $\begin{array}{l}0.15 \\
0.40 \\
0.42 \\
0.11 \\
1.02 \\
1.05 \\
0.97 \\
0.86 \\
0.91 \\
0.89 \\
0.22 \\
0.28\end{array}$ & $\begin{array}{l}316 \\
266 \\
380 \\
336 \\
151 \\
147 \\
153 \\
152 \\
140 \\
148 \\
300 \\
307\end{array}$ & $\begin{array}{l}\mathrm{D} \\
\mathrm{D} \\
\mathrm{D} \\
\mathrm{D} \\
\mathrm{R} \\
\mathrm{R} \\
\mathrm{R} \\
\mathrm{R} \\
\mathrm{R} \\
\mathrm{R} \\
\mathrm{D} \\
\mathrm{D}\end{array}$ & 8.390 & $\begin{array}{l}0.76 \\
0.66 \\
0.95 \\
0.85 \\
0.29 \\
0.25 \\
0.32 \\
0.31 \\
0.23 \\
0.26 \\
0.73 \\
0.75\end{array}$ & 0.80 & 0.80 \\
\hline \multicolumn{21}{|l|}{ Hole 320B } \\
\hline $\begin{array}{l}3-1,73-76 \\
3-1,136-139\end{array}$ & $\begin{array}{l}2.75 \\
2.73\end{array}$ & $\begin{array}{l}0.01 \\
0.12\end{array}$ & $\begin{array}{l}16.1 \\
13.3\end{array}$ & $\begin{array}{l}0.49 \\
0.49\end{array}$ & $\begin{array}{l}0.02 \\
0.01\end{array}$ & $\begin{array}{l}-20.9 \\
-25.0\end{array}$ & $\begin{array}{r}120.5 \\
25.5\end{array}$ & $\begin{array}{l}2.5 \\
2.6\end{array}$ & $\begin{array}{r}650 \\
>800\end{array}$ & $\begin{array}{l}500 \\
500\end{array}$ & $\begin{array}{l}3.84 \\
4.65\end{array}$ & $\begin{array}{l}-17.1 \\
-22.0\end{array}$ & $\begin{array}{r}119.7 \\
26.9\end{array}$ & $\begin{array}{l}0.06 \\
0.08\end{array}$ & $\begin{array}{l}330 \\
340\end{array}$ & $\begin{array}{l}\text { D } \\
\text { D }\end{array}$ & & $\begin{array}{l}0.81 \\
0.82\end{array}$ & & \\
\hline \multicolumn{21}{|l|}{ Site 321} \\
\hline $\begin{array}{l}14-1,52-55 \\
14-1,88-91 \\
14-2,49-52 \\
14-2,122-125 \\
14-3,4-7 \\
14-3,103-106 \\
14-4,42-45 \\
14-4,64-67\end{array}$ & $\begin{array}{l}2.87 \\
2.87 \\
2.96 \\
2.87 \\
2.88 \\
2.90 \\
2.92 \\
2.91\end{array}$ & $\begin{array}{l}2.29 \\
1.90 \\
2.75 \\
4.58 \\
3.79 \\
3.82 \\
4.94 \\
5.07\end{array}$ & $\begin{array}{r}8.8 \\
22.9 \\
19.1 \\
4.5 \\
4.7 \\
7.6 \\
7.6 \\
5.4\end{array}$ & $\begin{array}{r}6.26 \\
13.50 \\
16.30 \\
6.46 \\
5.58 \\
9.00 \\
11.70 \\
8.46\end{array}$ & $\begin{array}{l}0.34 \\
0.29 \\
0.71 \\
0.38 \\
0.38 \\
0.37 \\
0.82 \\
0.81\end{array}$ & $\begin{array}{r}-8.4 \\
-6.0 \\
-11.9 \\
-10.4 \\
-2.2 \\
-6.8 \\
-14.3 \\
-11.6\end{array}$ & $\begin{array}{r}348.6 \\
83.0 \\
105.7 \\
260.9 \\
242.0 \\
244.1 \\
14.1 \\
254.2\end{array}$ & $\begin{array}{l}2.2 \\
2.1 \\
1.3 \\
7.4 \\
6.1 \\
3.4 \\
1.9 \\
5.6\end{array}$ & $\begin{array}{r}75 \\
110 \\
70 \\
35 \\
60 \\
55 \\
40 \\
40\end{array}$ & $\begin{array}{l}200 \\
200 \\
150 \\
150 \\
150 \\
150 \\
150 \\
100\end{array}$ & $\begin{array}{r}8.12 \\
3.86 \\
42.50 \\
3.73 \\
5.65 \\
7.37 \\
9.42 \\
10.70\end{array}$ & $\begin{array}{r}-9.6 \\
-10.7 \\
-22.0 \\
-20.4 \\
-16.4 \\
-15.5 \\
-20.8 \\
-14.4\end{array}$ & $\begin{array}{r}352.1 \\
80.5 \\
103.9 \\
250.4 \\
245.7 \\
236.8 \\
19.0 \\
264.3\end{array}$ & $\begin{array}{l}1.37 \\
1.20 \\
1.41 \\
1.43 \\
1.55 \\
1.39 \\
1.36 \\
1.44\end{array}$ & $\begin{array}{l}162 \\
163 \\
150 \\
136 \\
160 \\
136 \\
125 \\
127\end{array}$ & $\begin{array}{l}\mathrm{R} \\
\mathrm{R} \\
\mathrm{R} \\
\mathrm{R} \\
\mathrm{R} \\
\mathrm{R} \\
\mathrm{R} \\
\mathrm{R}\end{array}$ & 8.463 & $\begin{array}{l}0.36 \\
0.36 \\
0.29 \\
0.22 \\
0.35 \\
0.22 \\
0.10 \\
0.13\end{array}$ & 0.43 & 0.37 \\
\hline
\end{tabular}

Note: $\rho$ : density, g/cc; $\chi$ : magnetic susceptibility, $10^{-3} / \mathrm{cc} ; Q$ : in situ ratio of remanent to induced magnetization; $J_{N}$ : intensity of natural remanent magnetization (NRM), $10^{-3} \mathrm{emu} / \mathrm{cc} ; \mathrm{SD} J_{N}$ standard deviation of NRM intensity, $10^{-3} \mathrm{emu} / \mathrm{cc} ; I_{N}$ : inclination of NRM, degrees, positive downward; $D_{N}$ : declination of NRM, degrees (arbitrary azimuths); $\delta N$ :rms deviation of NRM direction from mean, degrees $\left(J_{N}, I_{N}, D_{N}\right.$ are means of seven measurements); MDF: median demagnetizing field, peak oersteds; H: optimum demagnetizing field, peak oersteds; $J_{H}$ : intensity of NRM after AF demagnetization in field $\mathrm{H}, 10^{-4} \mathrm{emu} / \mathrm{cc} ; I_{H}$ : inclination of NRM after AF demagnetization in field $\mathrm{H}$, degrees, positive downward; $D_{H}$ : declination of $\mathrm{NRM}$ after $\mathrm{AF}$ demagnetization in field $\mathrm{H}$, degrees (same arbitrary azimuths as for $D_{N}$ ); $J_{s}$ : saturation-induced magnetization, emu/g; $T_{c}$ : Curie temperature, ${ }^{\circ} \mathrm{C}$; Type: thermomagnetic curve type (see text), $a$. cubic cell edge of magnetic concentrate, $\AA ; x$ : inferred original mole $\%$ of titanomaghemite: $z$ : oxidation parameter of titanomaghemite: $z\left(T_{c}\right)$, estimated from Curie temperature; $z(\mathrm{a})$, estimated from cell edge; $z$ (Fig. 4), determined from compositional diagram. 


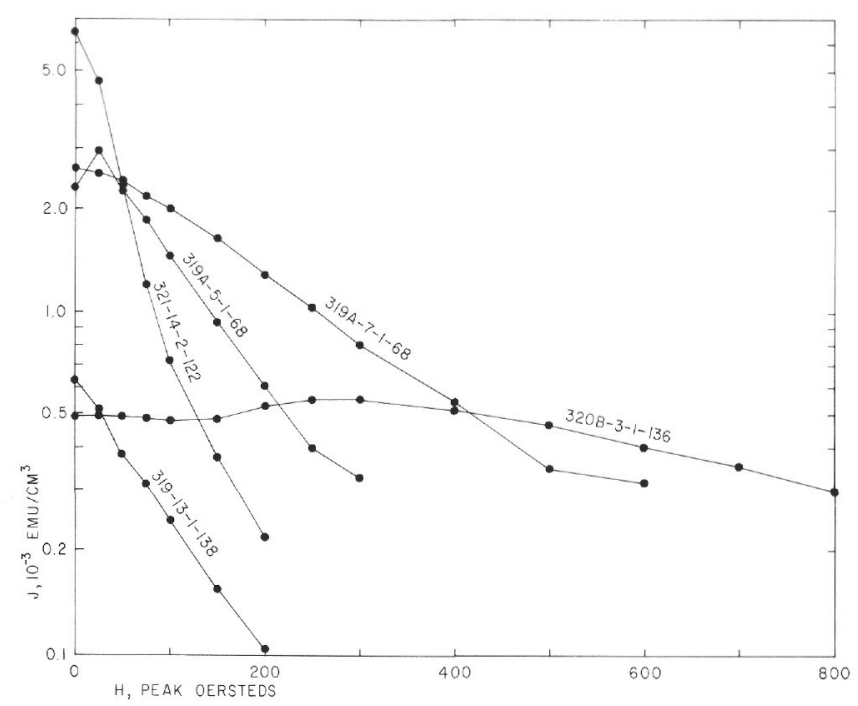

Figure 1. Representative alternating-field demagnetization curves. J is intensity of NRM. Starting values are means of seven measurements.

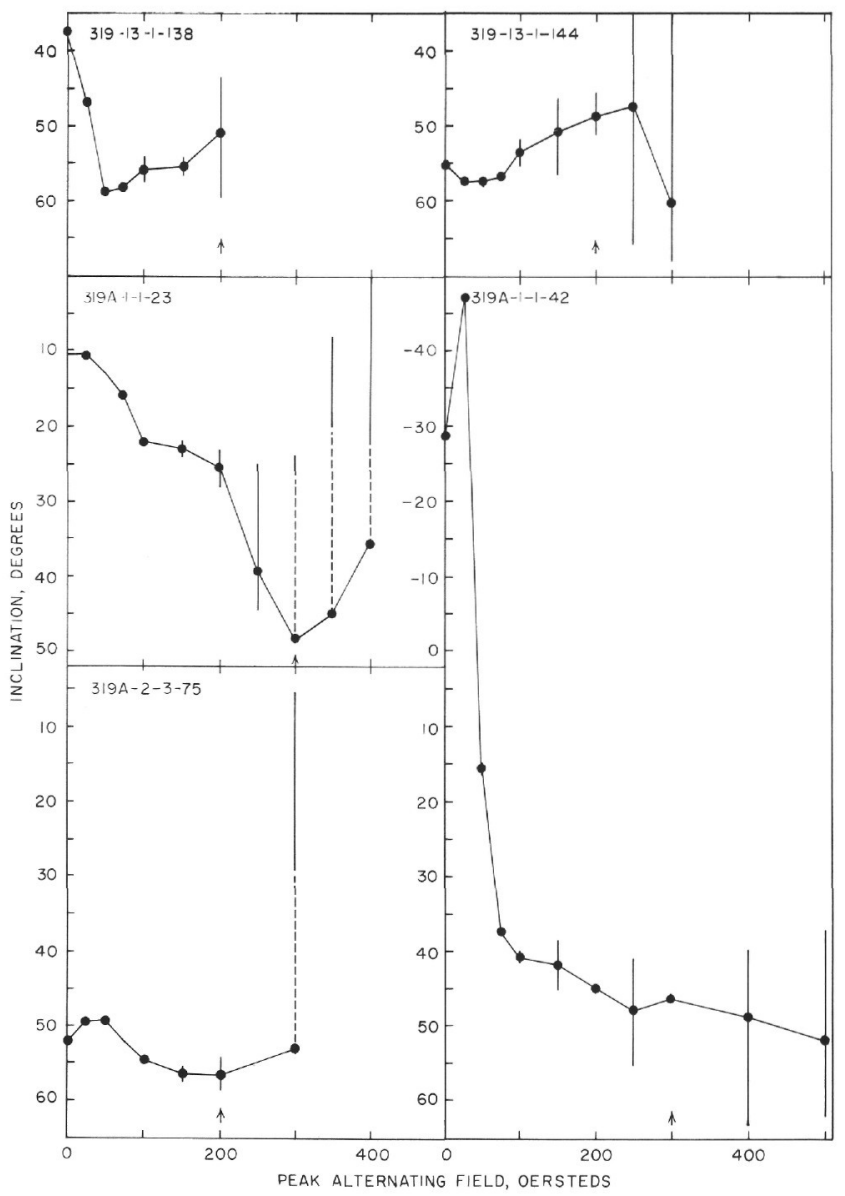

Figure 2a. Variation of inclination of NRM during alternating-field demagnetization for all samples. Starting values are last measurements, made just prior to demagnetization. See text for further explanation.

comparisons are of limited value because only one cooling unit is represented in Hole 320B, and probably no more than three are represented at Site 321; hence,

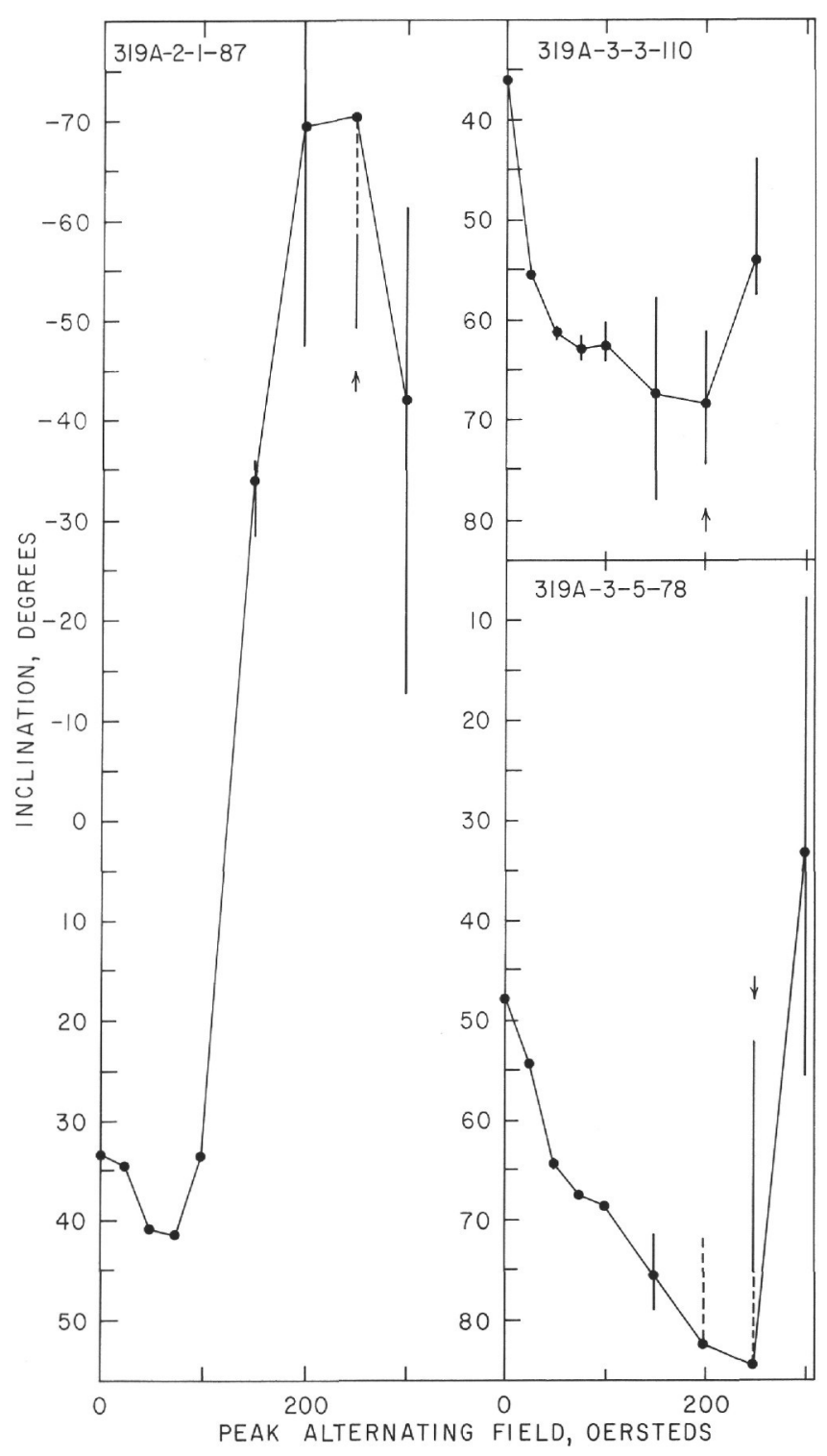

Figure 2b. Variation of inclination of NRM during alternating-field demagnetization for all samples. Starting values are last measurements, made just prior to demagnetization. See text for further explanation.

deviations in inclination arising from geomagnetic secular variation might be expected. For Sites 320 and 321 , we can say that the measured inclinations agree with those predicted from the simplest model, and thus there is no indication from these data that the latitude of the Nazca plate has changed appreciably since late Eocene time. On the other hand, the stable NRM inclinations for Holes 319 and 319A agree with each other but are clearly anomalous. Assuming that the NRM was acquired during a time of reversed geomagnetic polarity, the minimum latitude change of the Nazca plate required to fit the data is on the order of $26^{\circ}$ northward since early Miocene time, which is unlikely. The most convenient explanation for these anomalously steep inclinations is tectonic slumping of a large block of basement rock, shortly after its formation at the former spreading center represented by the Galapagos Rise. 


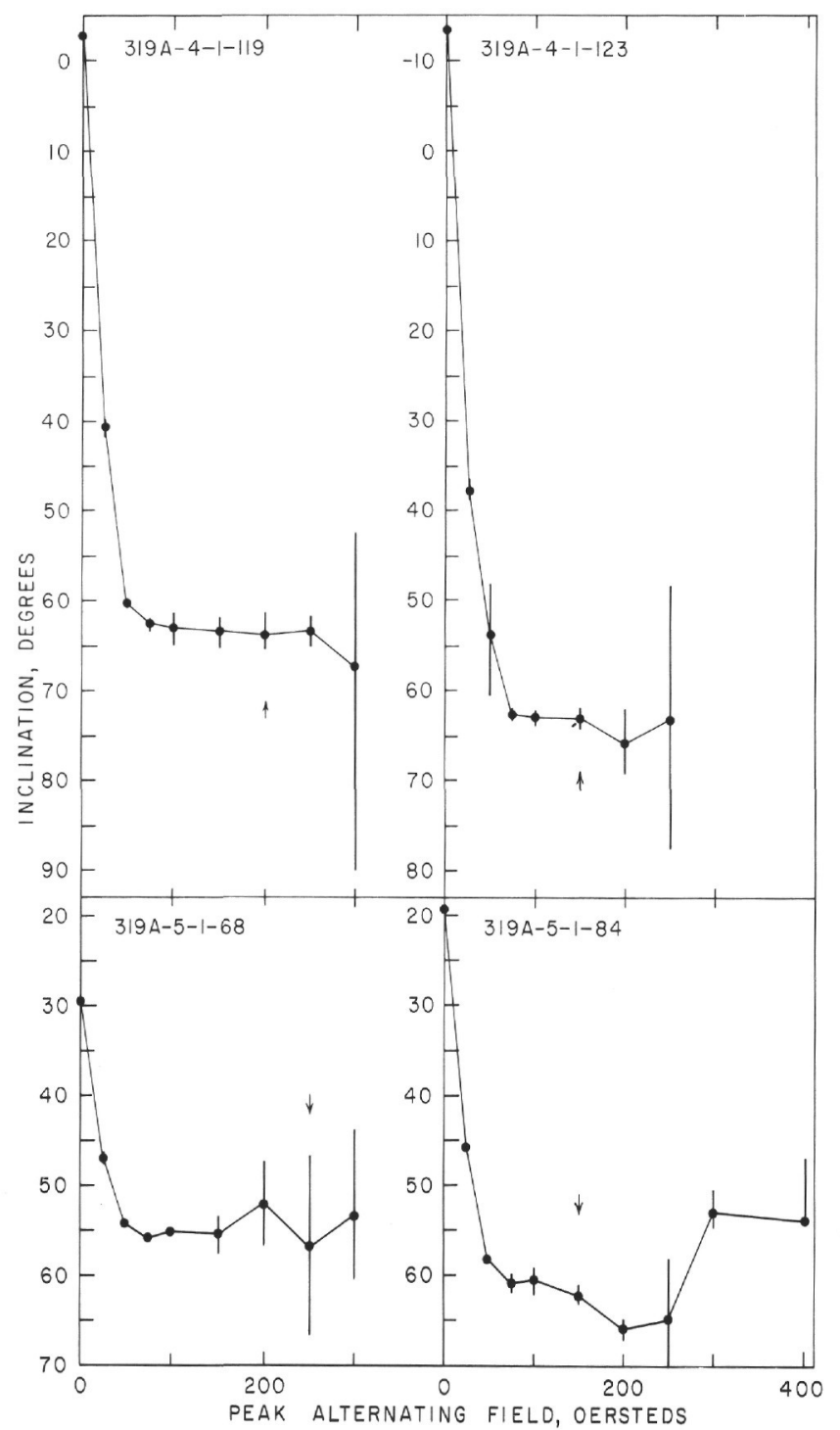

Figure 2c. Variation of inclination of NRM during alternating-field demagnetization for all samples. Starting values are last measurements, made just prior to demagnetization. See text for further explanation.

Another possible cause of the steep inclinations is that the rocks were initially magnetized during a brief interval of anomalous geomagnetic field direction, such as during a reversal or "excursion," but this seems less likely because at least five cooling units are represented in the data for these holes, and no nonanomalous inclinations are observed.

\section{MAGNETIC MINERALOGY}

Strong-field thermomagnetic curves were obtained for all specimens, and representative results are shown in Figure 3. A-1 of the curves fell into one or the other of two types, both illustrated by Marshall and Cox (1972, fig. 5), for pillow basalt. In type $D$, the heating curve shows an initial Curie temperature between $200^{\circ}$ and $400^{\circ} \mathrm{C}$, an increase in magnetization usually occurs between $400^{\circ}$ and $500^{\circ} \mathrm{C}$, both heating and cooling

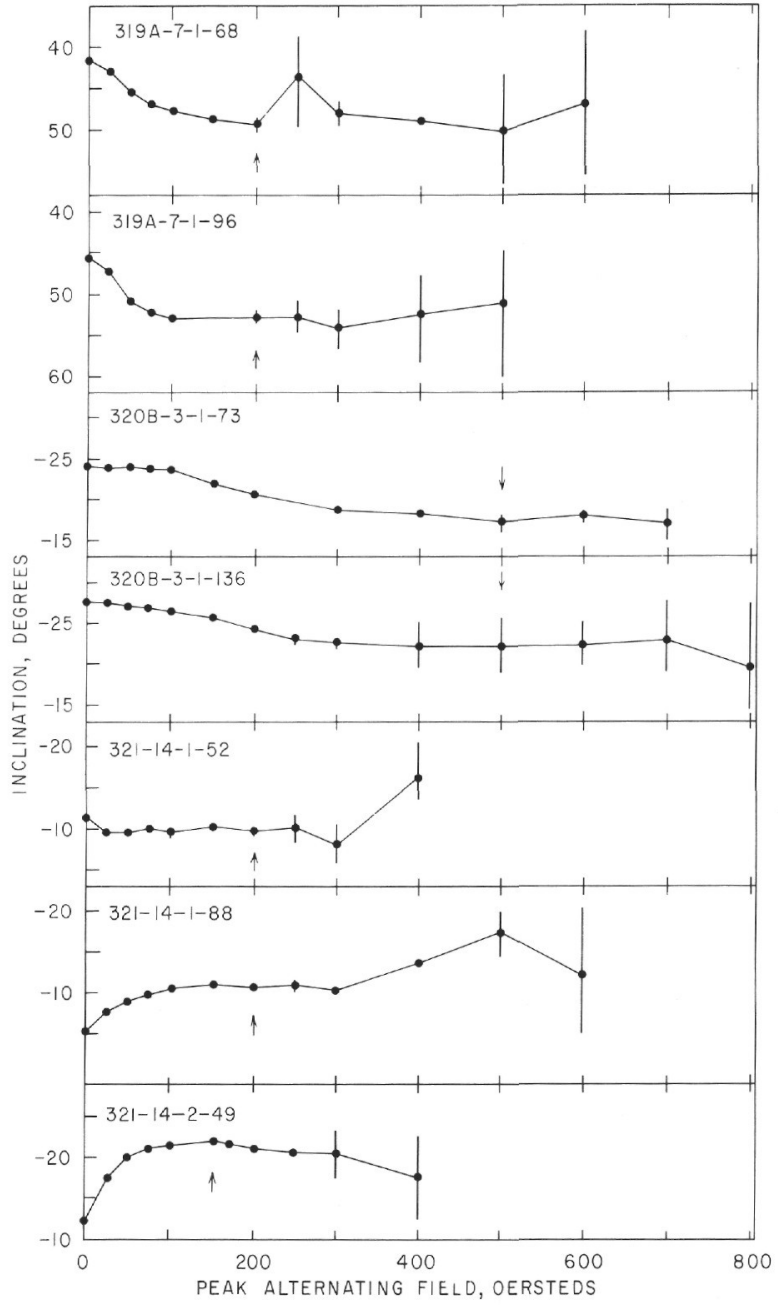

Figure 2d. Variation of inclination of NRM during alternating-field demagnetization for all samples. Starting values are last measurements, made just prior to demagnetization. See text for further explanation.

curves show Curie temperatures in the vicinity of $550^{\circ} \mathrm{C}$, and the magnetization after cooling is from two to seven times greater than the initial value. Under the experimental conditions described above (vacuum), this type of thermomagnetic curve is diagnostic of titanomaghemite, the cation-deficient spinel that is the product of low temperature oxidation of titanomagnetite (Readman and O'R eilly, 1970; Marshall and Cox, 1972). Type $\mathrm{R}$ thermomagnetic curves are characterized by initial Curie temperatures below $200^{\circ} \mathrm{C}$, no reactions at higher temperature in vacuum, and a magnetization after cooling that is nearly the same as the initial value. Clearly the disproportionation of titanomaghemite into various breakdown products that is represented in the type D curves (Readman and O'Reilly, 1970) does not occur in the type $\mathrm{R}$ curves. The systematic errors in measuring temperatures below $200^{\circ} \mathrm{C}$ in vacuum are clearly illustrated in Figure 3 by the differences between the heating and cooling curves for type $\mathbf{R}$ samples, although part of these differences is due to partial reduction of titanomaghemite at higher temperatures 


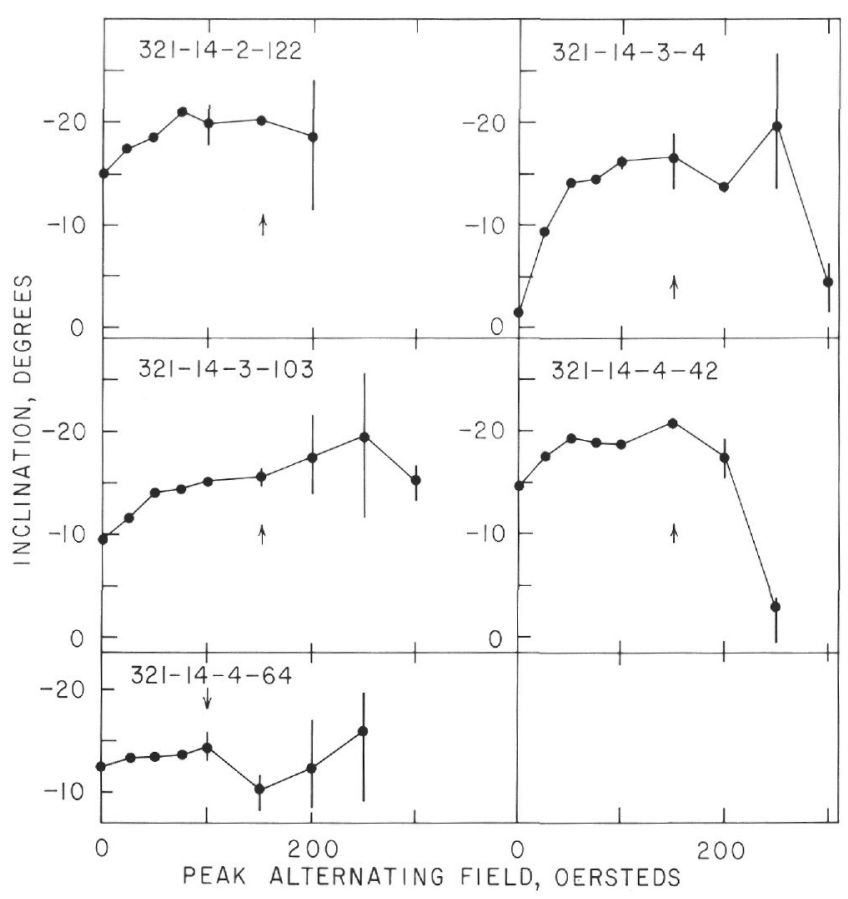

Figure 2e. Variation of inclination of NRM during alternating-field demagnetization for all samples. Starting values are last measurements, made just prior to demagnetization. See text for further explanation.

(Marshall and Cox, 1972). If type $\mathrm{R}$ samples are heated no higher than $300^{\circ} \mathrm{C}$ in nitrogen, no chemical reaction occurs and cooling curves closely retrace heating curves. Saturation magnetizations before heating, the initial Curie temperatures, and the thermomagnetic curve types are listed for all specimens in Table 1.

To confirm our interpretation of the thermomagnetic curves, cubic cell dimensions were determined for magnetic concentrates obtained from representative specimens, and the results are given in Table 1. Using the experimental data of Readman and O'Reilly (1972) as coordinates, we have indicated in Figure 4 the compositions of the magnetic concentrates derived from their Curie temperatures and cell dimensions. It is clear from this diagram that all these specimens are oxidized (i.e., are titanomaghemites) but that type-D thermomagnetic curves indicate a much higher degree of oxidation than do type- $R$ curves. In.Figure 4 we have shown a dashed line to indicate the composition path followed during low temperature oxidation of these titanomaghemites. Extrapolation of this line to the magnetite-ulvöspinel join allows an estimate to be made of $x$, the mole percentage of ulvöspinel that may be presumed to represent the composition of stoichiometric titanomagnetite at the time of initial crystallization, prior to oxidation. The value of $x$ from Figure 4 is 0.65 .

The dashed line in Figure 4 is not quite parallel to the base of the diagram, and its slope suggests a slight decrease in iron-titanium ratio during oxidation. Whether the iron-titanium ratio in titanomagnetite is preserved during oxidation on the sea floor depends on the details of the course of the reaction. Two alternatives are likely. The first, which pertains to experiments with
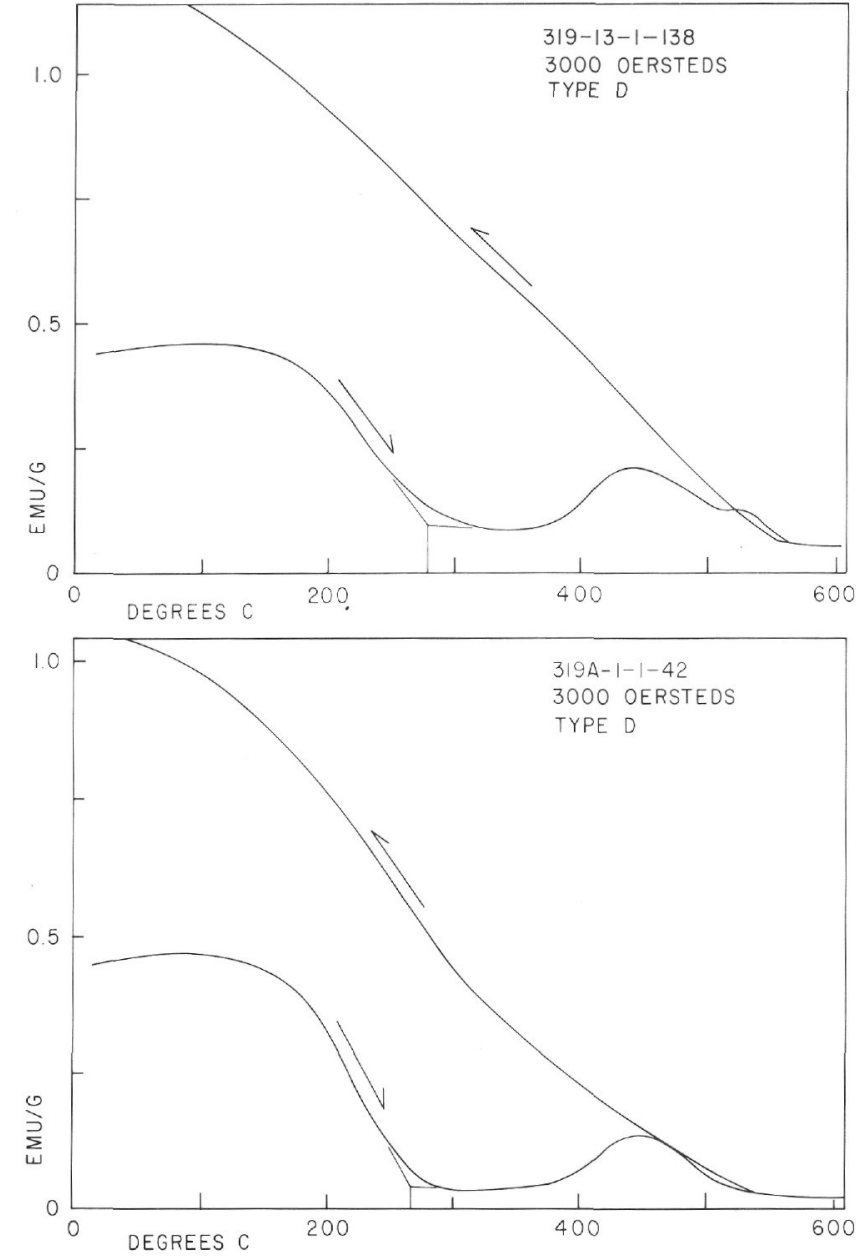

Figure 3a. Variation of strong-field induced magnetization with temperature for representative specimens. For type$D$ samples, all runs were made in vacuum. For type- $R$ samples, runs made in vacuum are shown by dashed curves, and runs made in nitrogen are shown by solid curves. Heating and cooling curves are indicated by arrows. The graphical method of Curie temperature determination is indicated by short straight lines.

artificial materials (Readman and O'Reilly, 1970, 1972), is that all of the $\mathrm{Fe}^{2+}$ ions that diffuse out of the original oxide lattice to be oxidized to $\mathrm{Fe}^{3+}$ are combined with oxygen at the crystal surfaces, resulting in no net change in $\mathrm{Fe} / \mathrm{Ti}$ ratio. The second alternative is that part or all of the $\mathrm{Fe}^{2+}$ ions that leave the original oxide lattice and are oxidized to $\mathrm{Fe}^{3+}$ migrate away from the original crystal surfaces and form new minerals in the rock (Marshall and Cox, 1972), resulting in a decrease in the $\mathrm{Fe} / \mathrm{Ti}$ ratio of the magnetic oxides. Experimental evidence favoring the latter mechanism in a single partly oxidized submarine pillow lava fragment has been presented by Marshall and Cox (1972). Reduction of $\mathrm{Fe} / \mathrm{Ti}$ ratio during low-temperature oxidation is also suggested by the data from subaerial basalts (Creer and Ibbetson, 1970, fig. 10). Moreover, we should point out that in the absence of data to the contrary, we have assumed that the magnetic minerals are pure Fe-Ti oxides and that effects on Curie temperatures and cell 

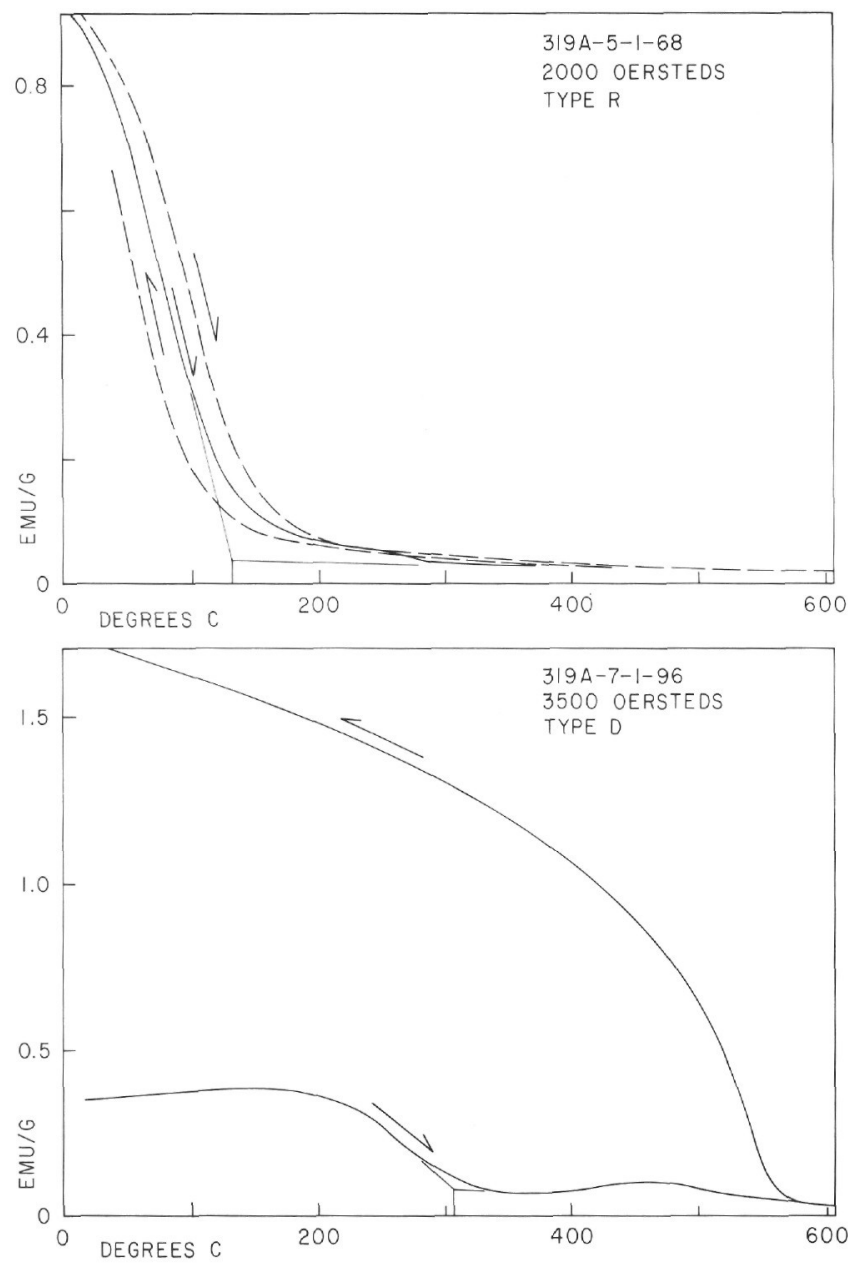

Figure 3b. Variation of strong-field induced magnetization with temperature for representative specimens. For type$D$ samples, all runs were made in vacuum. For type- $R$ samples, runs made in vacuum are shown by dashed curves, and runs made in nitrogen are shown by solid curves. Heating and cooling curves are indicated by arrows. The graphical method of Curie temperature determination is indicated by short straight lines.

dimensions of possible minor constituents such as $\mathrm{Mg}$ and Al are negligible. Readman and O'Reilly (1972) have pointed out that this may not be true.

The oxidation parameter $z$ for titanomaghemites is defined as the mole fraction of the total $\mathrm{Fe}^{2+}$ ions initially present in the mineral that has been oxidized to $\mathrm{Fe}^{3+}$ (O'Reilly and Banerjee, 1967). We list in Table 1 very approximate estimates of $z$ made in the following two ways. Assuming that the original $x$ for all samples is 0.65 , the measured Curie temperatures were used to find $z$ values for all specimens by interpolating on fig. 3 of Readman and O'Reilly (1972). For the samples with measured cubic cell edges, a similar procedure was used with fig. 1 of Readman and O'Reilly (1972). The values of $z$ obtained in these two ways may be compared (Table 1) and are mostly in good agreement with each other and with values read directly from Figure 4 . We note, however, that this agreement does not substantiate our

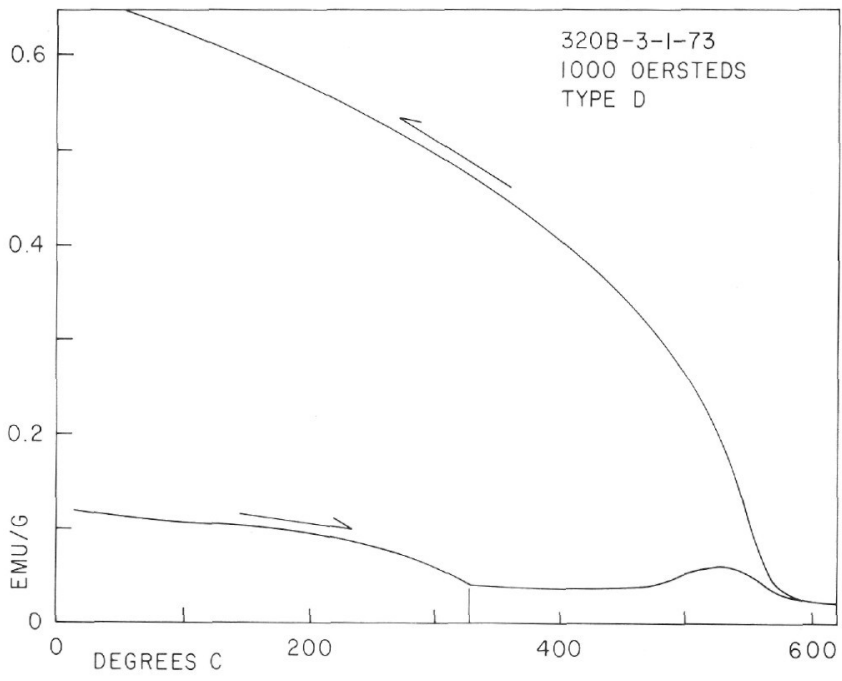

Figure 3c. Variation of strong-field induced magnetization with temperature for representative specimens. For type$D$ samples, all runs were made in vacuum. For type- $R$ samples, runs made in vacuum are shown by dashed curves, and runs made in nitrogen are shown by solid curves. Heating and cooling curves are indicated by arrows. The graphical method of Curie temperature determination is indicated by short straight lines.

assumption that $x \cong 0.65$ is the true initial value because overestimating $x$ will also cause $z$ to be overestimated when found by either method alone. Values of $z$ found from the molecular composition diagram (Figure 4 and Table 1) are independent of the choice of initial $x$ values. From these data, it does appear that the transition from type-R to type-D thermomagnetic curves occurs for a $z$ value somewhere between 0.4 and 0.6 .

\section{DISCUSSION}

Because this sample collection is heterogeneous with respect to such variables as grain size and unknown aspects of the rocks' geologic history, not to mention geographic location and age, attempts at detailed correlation of magnetic properties are not very productive. Nonetheless, some definite generalizations may be made. The rocks fall clearly into two groups: those containing moderately oxidized titanomagnetites, having $z$ between 0.10 and 0.36 and giving type- $R$ thermomagnetic curves; and those containing strongly oxidized titanomagnetites, with $z$ between 0.60 and 0.95 , giving type-D thermomagnetic curves. There is a definite tendency for the R group to have stronger NRM intensities, although this is unduly enhanced by the strong NRMs found in all samples from Site 321. Considering only Holes $319,319 \mathrm{~A}$, and $320 \mathrm{~B}$, the $\mathrm{R}$ group carries about three times as much NRM as the D group, with the only overlap being the strongly magnetized type-D specimens from the bottom of Hole 319A. Thus, it is clear that, other factors being equal, oxidation diminishes NRM intensity.

The effect of oxidation on magnetic hardness is of considerable practical concern. There are no differences in the mean percentage standard deviations of NRM in- 

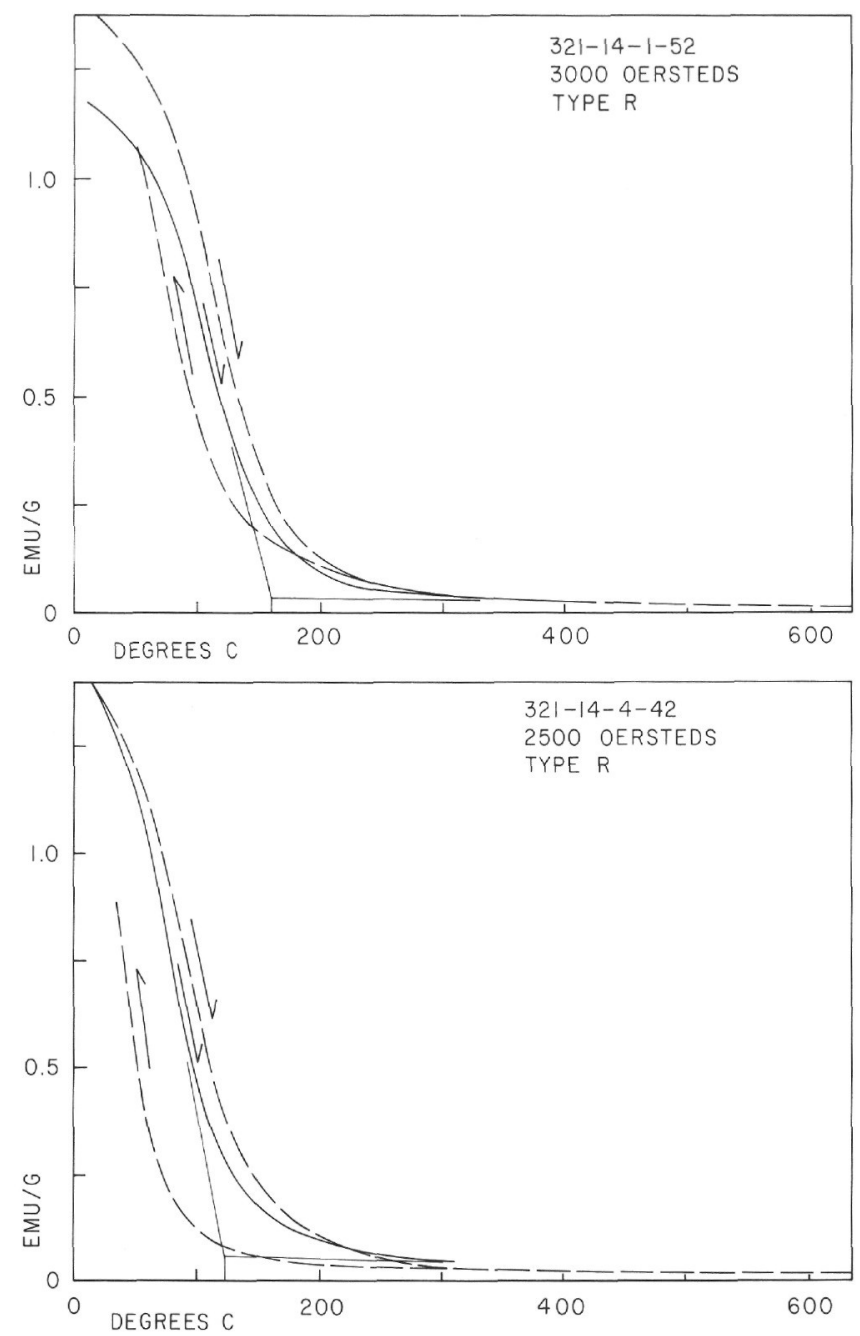

Figure 3d. Variation of strong-field induced magnetization with temperature for representative specimens. For type$D$ samples, all runs were made in vacuum. For type- $R$ samples, runs made in vacuum are shown by dashed curves, and runs made in nitrogen are shown by solid curves. Heating and cooling curves are indicated by arrows. The graphical method of Curie temperature determination is indicated by short straight lines.

tensities or mean rms angular deviations of NRM directions between the $\mathrm{R}$ and $\mathrm{D}$ groups, so that oxidation does not seem to affect the net ability of these rocks to acquire short-term viscous magnetization. The effect of oxidation on the median demagnetizing field is pronounced, however. The mean MDF for all $\mathrm{R}$ samples is 65 oe \pm 19 oe (SD), and there is no difference between the $R$ samples from Hole 319A and Site 321. MDF values for Hole $320 \mathrm{~B}$ are very high because of the unusually fine grain size of the specimens. The mean MDF for the D samples from Holes 319 and 319A is 159 oe \pm 69 oe (SD), about two and a half times greater than the $\mathrm{R}$ group, so that oxidation either increases the hardness of stable NRM or eliminates the fractions of stable NRM with lower coercivities.

Susceptibilities are markedly lower for more oxidized specimens: the mean for the $\mathrm{R}$ group is $3.3 \times 10^{-3} \pm 1.0$

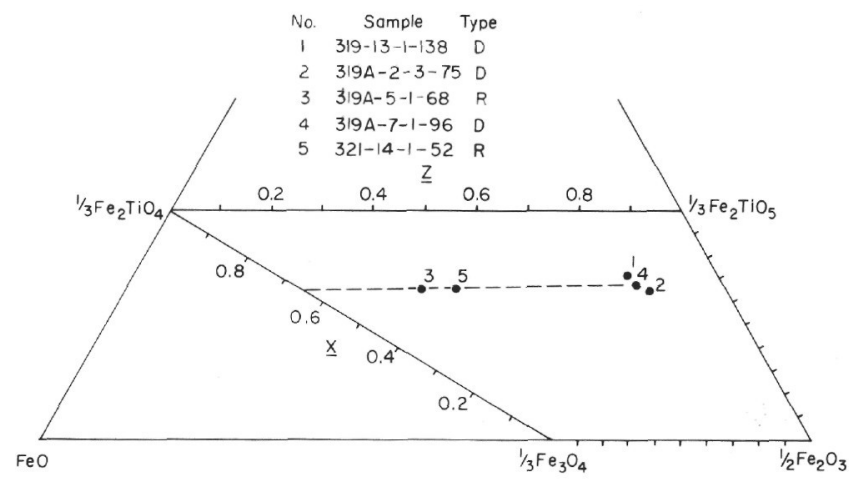

Figure 4. Titanomaghemite part of $\mathrm{FeO}-\mathrm{Fe}_{2} \mathrm{O}_{3}-\mathrm{TiO}_{2}$ mole $\%$ compositional triangle. Compositions of titanomaghemites shown are determined from cubic cell dimensions of magnetic concentrates and from Curie temperatures found from heating parts of thermomagnetic curves (Tabie 1). Intersection of dashed line with magnetite-ulvospinel join indicates inferred original composition of titanomagnetites prior to oxidation.

$\times 10^{-3}(\mathrm{SD})$ and the mean for the $\mathrm{D}$ group is $0.32 \times 10^{-3}$ $\pm 0.22 \times 10^{-3}(\mathrm{SD})$, only one-tenth as great. Saturation magnetization is dependent only on the volume proportion, chemical composition, and crystal structure of the ferrimagnetic minerals in the rock, while susceptibility can also depend on size and shape of ferrimagnetic grains and such factors as dislocation density or physical impurities. Hence, saturation magnetization $\left(\mathrm{J}_{s}\right)$ is a more direct measure of changes in magnetic minerals in a rock. $J_{s}$ is plotted against $z$ for all samples in Figure 5, and several striking features may be seen. $J_{S}$ is significantly higher in the samples from Site 321 than in the $\mathrm{R}$ samples from Hole $319 \mathrm{~B}$, although the ranges of $z$ values for the two groups are similar. This may partly explain the higher NRM intensities in samples from Site 321 as resulting from a larger proportion of original titanomagnetite.

For all samples in the D group except one (319A-2-1, $87 \mathrm{~cm}), J_{s}$ plotted against $z$ seems to define a straight line (Figure 5) that approaches closely the $J_{s}=0$ axis and would cross it somewhere between $z=0.85$ and $z=$ 0.90 . This may be interpreted as an indication that in the vicinity of $0.85 \leq z \leq 0.90$ and $x \cong 0.65$ the spontaneous magnetizations of the $A$ and $B$ sublattices in these cation-deficient spinels are equal and hence cancel, as predicted by O'Reilly and Banerjee (1967). Oxidation beyond this point would result in the net magnetization being transferred from the B sublattice to the A sublattice, and $J_{s}$ would again increase with increasing $z$, although the spontaneous magnetization would actually have the opposite sign. This seems to be the case for Sample 319A-2-1, $87 \mathrm{~cm}$ which is the most highly oxidized $(z=0.95)$ of all the samples. In Figure 5, the point for this sample is also shown reflected to the equivalent negative value of $J_{s}$, where it lies near (but not on) the prolongation of the straight line defined by the other type-D samples. The distribution of points in Figure 5, particularly for the type-D samples, is very similar to the data for artificial titanomaghemites with $x=0.7$ shown by Readman and O'Reilly (1972, fig. 2c). Readman and 


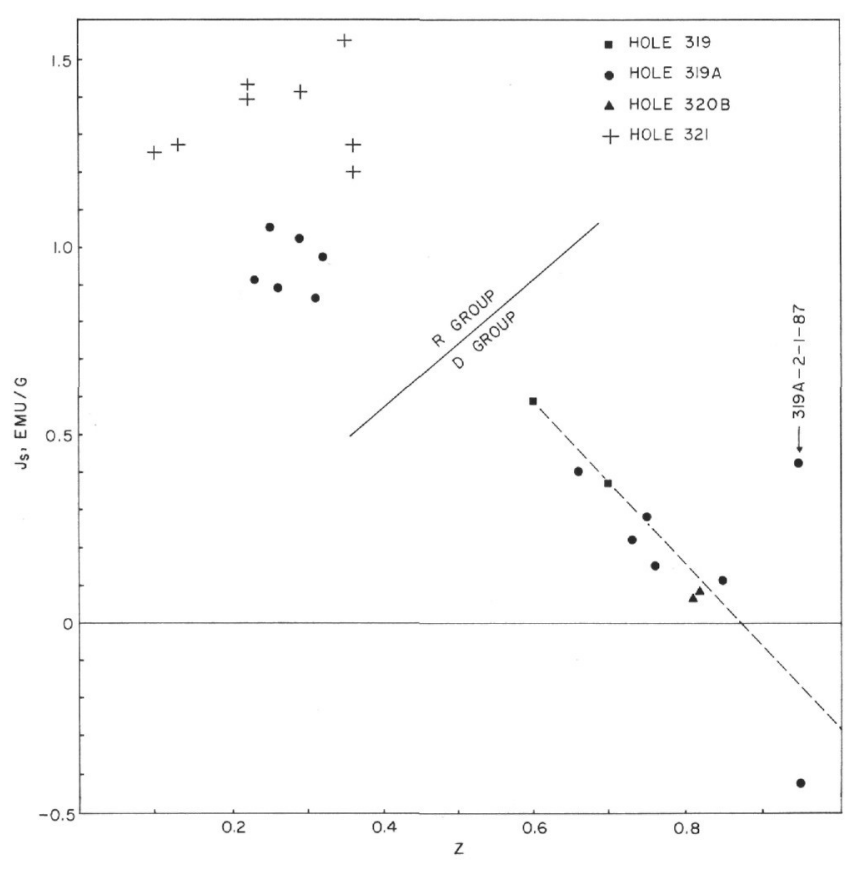

Figure 5. Saturation induced magnetization plotted against oxidation parameter $\mathrm{z}$ for all samples. The dashed line indicates the inferred variation of $\mathrm{J}_{\mathrm{S}}$ with $\mathrm{z}$ for strongly oxidized sample, 319A-2-1, $87 \mathrm{~cm}$, is plotted twice, for negative and positive $\mathrm{J}_{\mathrm{S}}$, indicating the possibility of selfreversal.

O'Reilly's data were obtained at $4.2^{\circ} \mathrm{K}$, whereas ours were obtained at $298^{\circ} \mathrm{K}$ so that the agreement may be partly fortuitous.

Verhoogen (1962) has suggested that transfer of the net magnetization of titanomaghemite from the B sublattice to the $A$ sublattice through progressive low temperature oxidation might result in self-reversal of NRM. The stable NRM of this sample indeed has negative inclination while the three samples below it that apparently are from the same cooling unit have positive inclinations, and the absolute values of inclinations within this cooling unit are similar (Table 1). We note that Sample 319A-2-1, $87 \mathrm{~cm}$ was cut from a very small fragment of drill core, so the orientation may have been lost during drilling. Nonetheless, the strongest evidence seems to be that the NRM of this sample is truly selfreversed.

An important question is whether the original NRM directions have been reliably preserved during the pervasive oxidation of the titanomagnetites. Much of this oxidation may have occurred during the first few tens of thousands of years of the rocks' history, with the remainder being much more gradual (Irving et al., 1970a). Thus, if oxidation produces chemical remanent magnetization (CRM) in the basalts (Johnson and Merrill, 1973), much of this CRM will usually be acquired in a magnetic field similar to that in which the lavas originally cooled. However, if CRM is produced over a sufficient length of time to allow geomagnetic polarity reversals or plate motion to change the ambient field significantly, the effect might be observed as anomalous NRM directions. Anomalous NRM direc- tions are not observed in the rocks from Sites 320 and 321 , but changes in Nazca plate latitude have apparently been insignificant, so that no evidence about possible effects of CRM can be deduced. If, on the other hand, the anomalously steep inclinations of NRM at Site 319 result either from tectonic slumping at the Galapagos Rise or from a brief period of anomalous geomagnetic field direction during initial cooling of the lavas, the effect of CRM acquired later might be observable. The mean inclination in the more oxidized (type-D) specimen from Site 319 is $14^{\circ}$ shallower than the mean inclination in the less oxidized (type-R) specimens (Table 1). The significance of this difference is hard to assess because of the small number of cooling units, but the change is what would be predicted if the type-D rocks had acquired significantly more CRM than the type- $\mathrm{R}$ rocks.

\section{SUMMARY}

Mean paleomagnetic inclinations in basaltic rocks at Sites 320 and 321 do not differ significantly from the geocentric axial dipole field directions at those localities, so that no significant latitudinal motion of the Nazca plate since late Eocene time can be inferred from the data. Inclinations in basaltic rocks at Site 319 are anomalously steep; these cannot be explained by a reasonable model of plate motion but may be due to tectonic slumping at the Galapagos $R$ ise or to an anomalous geomagnetic field direction when the rocks were formed. Improvement in AF demagnetization techniques has led to significantly more reliable identification of stable NRM directions in these magnetically soft rocks. Intensities of NRM, magnetic susceptibility, and other magnetic parameters are similar to those reported for DSDP basalts from the Pacific plate, but the NRM intensities are lower and the susceptibilities are higher than values reported in many studies of dredged deep-sea pillow basalts. Evidence of low temperature oxidation of original titanomagnetite to the cation-deficient spinel titanomaghemite was found in all samples. From thermomagnetic analysis supplemented by X-ray diffraction, two categories of titanomaghemites could be clearly distinguished: moderately oxidized with from $10 \%$ to $36 \%$ of original $\mathrm{Fe}^{2+}$ changed to $\mathrm{Fe}^{3+}$, and strongly oxidized with from $60 \%$ to $95 \%$ of original $\mathrm{Fe}^{2+}$ changed to $\mathrm{Fe}^{3+}$. The effect of this oxidation has been to reduce the NRM intensity, the susceptibility, and the saturation magnetization. In comparison with the moderately oxidized group of samples, strong oxidation has not affected the ability of the rocks to acquire short-term viscous magnetization but has markedly increased the coercivity of the stable NRM. The most oxidized sample appears to have undergone a spontaneous self-reversal of its NRM. Possible evidence of significant chemical remanent magnetization arising from gradual oxidation over a long period of time has been found in the basalts from Site 319 .

\section{ACKNOWLEDGMENTS}

Many discussions with Monte Marshall have contributed greatly to our understanding of the magnetic properties of deep-sea basalts. John Hillhouse and Allan Cox first suggested to us the vectorial method of eliminating effects of spurious 
magnetization during AF demagnetization. We thank Allan Cox for providing use of the shielded magnetometer.

\section{REFERENCES}

Akimoto, S., Katsura, T., and Yoshida, M., 1957. Magnetic properties of $\mathrm{TiFe}_{2} \mathrm{O}_{4}-\mathrm{Fe}_{3} \mathrm{O}_{4}$ system and their change with oxidation: J. Geomag. Geoelec., v. 9, p. 165.

Creer, K.M. and Ibbetson, J.D., 1970. Electron microprobe analyses and magnetic properties of non-stoichiometric titanomagnetites in basaltic rocks: Geophys. J. Roy. Astron. Soc., v. 21, p. 485.

Doell, R.R. and Cox, A., 1965. Measurement of the remanent magnetization of igneous rocks: U.S. Geol. Surv. Bull. 1203-A, p. 1-32. 1967a. Analysis of alternating field demagnetization equipment. In Collinson, D.W., Creer, K.M., and Runcorn, S.K. (Eds.), Methods in paleomagnetism: Amsterdam (Elsevier), p. 241-253.

1967b. Recording magnetic balance. In Collinson, D.W., Creer, K.M., and Runcorn, S.K. (Eds.), Methods in paleomagnetism: Amsterdam (Elsevier), p. 440-444.

Fox, P.J. and Opdyke, N.D., 1973. Geology of the oceanic crust: Magnetic properties of oceanic rocks: J. Geophys. Res., v. 78, p. 5139.

Grommé, C.S., Wright, T.L., and Peck, D.L., 1969. Magnetic properties and oxidation of iron-titanium oxide minerals in Alae and Makaopuhi lava lakes, Hawaii: J. Geophys. Res., v. 74, p. 5277 .

Irving, E., Park, J.K., Haggerty, S.E., Aumento, F., and Loncarevic, B., 1970a. Magnetism and opaque mineralogy of basalts from the Mid-Atlantic Ridge at $45^{\circ} \mathrm{N}$.: Nature, v. 228, p. 974.

Irving, E., Robertson, W.A., and Aumento, F., 1970b. The Mid-Atlantic Ridge near $45^{\circ} \mathrm{N}$. VI. Remanent intensity, susceptibility, and iron content of dredged samples: Canada J. Earth Sci., v. 7, p. 226.

Johnson, H.P. and Merrill, R.T., 1973. Low-temperature oxidation of a titanomagnetite and the implications for paleomagnetism: J. Geophys. Res., v. 78, p. 4938.

Lowrie, W., Lovlie, R., and Opdyke, N.D., 1973. Magnetic properties of Deep-Sea Drilling Project basalts from the North Pacific ocean: J. Geophys. Res., v. 78, p. 7647.

Marshall, M. and Cox, A., 1971. Magnetism of pillow basalts and their petrology: Geol. Soc. Am. Bull., v. 82, p. 537. 1972. Magnetic changes in pillow basalt due to sea floor weathering: J. Geophys. Res., v. 77, p. 6459.

O'Reilly, W. and Banerjee, S.K., 1967. The mechanism of oxidation in titanomagnetites: a magnetic study: Mineral. Mag., v. 36, p. 29.

Ozima, M. and Larson, E.E., 1970. Low- and hightemperature oxidation of titanomagnetite in relation to irreversible changes in the magnetic properties of submarine basalts: J. Geophys. Res., v. 75, p. 1003.

Prévot, M. and Grommé, C.S., 1975. Intensity of magnetization of subaerial and submarine basalts and its possible change with time: Geophys. J. Roy. Astron. Soc., v. 40, p. 207.

Readman, P.W. and ('Reilly, W., 1970. The synthesis and inversion of non-stoichiometric titanomagnetites: Phys. Earth Planet. Int., v. 4, p. 121.

1972. Magnetic properties of oxidized (cationdeficient) titanomagnetites (Fe, $\mathrm{Ti}, \square)_{3} \mathrm{O}_{4}$ : J. Geomag. Geoelec., v. 24, p. 69.

Verhoogen, J., 1962. Oxidation of iron-titanium oxides in igneous rocks: J. Geol., v. 70, p. 168.

Wilson, R.L., 1959. Remanent magnetism of late Secondary and early Tertiary British rocks: Phil. Mag., v. 4, p. 750.

Wilson, R.L. and Lomax, R., 1972. Magnetic remanence related to slow rotation of ferromagnetic material in alternating magnetic fields: Geophys. J. Roy. Astron. Soc., v. 30 , p. 295 . 